慶應義塾大学学術情報リポジトリ

Keio Associated Repository of Academic resouces

\begin{tabular}{|c|c|}
\hline Title & Inhibition of microtubule polymerization by synthetic estrogens : formation of a ribbon structure \\
\hline \multicolumn{2}{|l|}{ Sub Title } \\
\hline Author & 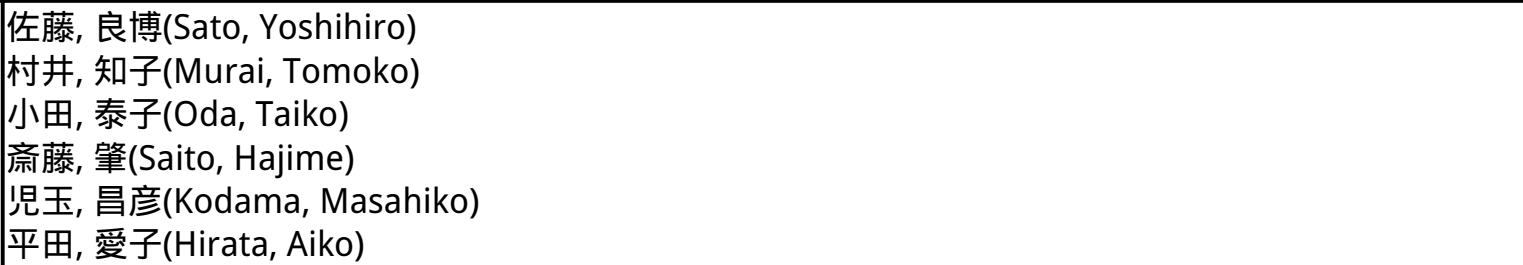 \\
\hline Publisher & 共立薬科大学 \\
\hline Publication year & 1987 \\
\hline Jtitle & $\begin{array}{l}\text { 共立薬科大学研究年報 (The annual report of the Kyoritsu College of } \\
\text { Pharmacy). No.32 (1987. ) ,p.64- } 64\end{array}$ \\
\hline \multicolumn{2}{|l|}{ JaLC DOI } \\
\hline \multicolumn{2}{|l|}{ Abstract } \\
\hline Notes & 抄録 \\
\hline Genre & Technical Report \\
\hline URL & $\begin{array}{l}\text { https://koara.lib.keio.ac.jp/xoonips/modules/xoonips/detail.php?koara_id=AN00062898-0000003 } \\
\text { 2-0064 }\end{array}$ \\
\hline
\end{tabular}

慶應義塾大学学術情報リポジトリ(KOARA)に掲載されているコンテンツの著作権は、それぞれの著作者、学会または出版社/発行者に帰属し、その権利は著作権法によって 保護されています。引用にあたっては、著作権法を遵守してご利用ください。

The copyrights of content available on the KeiO Associated Repository of Academic resources (KOARA) belong to the respective authors, academic societies, or publishers/issuers, and these rights are protected by the Japanese Copyright Act. When quoting the content, please follow the Japanese copyright act. 


\title{
Inhibition of Microtubule Polymerization by Synthetic Estrogens: Formation of a Ribbon Structure*
}

\author{
Yoshihiro Sato, Tomoko Murai, Taiko Oda, Hazime SaItô**, \\ Masahiko Kodama** and Aiko Hirata*** \\ 佐藤良博, 村井知子, 小田泰子, 斎藤 肇**, 児玉昌彦**, 平田愛子***
}

Dienestrol, meso-hexestrol, and dl-hexestrol, synthetic nonsteroidal estrogens, were shown to be inhibitors of microtubule assembly in vitro using microtubule proteins isolated from porcine brains. The order of activity of the synthetic estrogens as inhibitors of microtubule assembly is : dienestrol $>$ diethylstilbestrol $>$ meso-hexestrol $>$ dl-hexestrol $>$ isodienestrol. The activity of dienestrol as an inhibitor was almost in the same order with that of $(+)$-griseofulvin as determined by turbidity measurement. Electron microscopic observation revealed that twisted ribbon structures are formed from microtubule proteins in the presence of some synthetic estrogens (dienestrol, meso-hexestrol, and dl-hexestrol).<smiles>CC/C(=C(\CC)c1ccc(O)cc1)c1ccc(O)cc1</smiles>

a

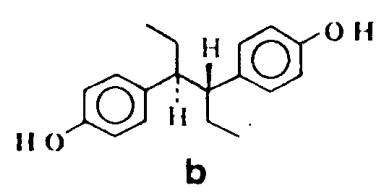

b<smiles>CCC(c1ccc(O)cc1)C(CC)(CC)c1ccc(O)cc1</smiles>

c<smiles>C/C=C(\C=C(/C)c1ccc(O)cc1)c1ccc(O)cc1</smiles><smiles>C/C=C(C(=C\C)\c1ccc(O)cc1)/c1ccc(O)cc1</smiles>

Fig. 1. Structures of synthetic estrogens : a, diethylstilbestrol ; b, meso-hexestrol ; c, $d l$-hexestrol (3S, 4S isomer) ; d, dienestrol ; and e, isodienestrol.

* 本報告は J. Biochem., 101, 1247-1252（1987）に発表.

** 国立がんセンタ一研

*** 東大応微研 